\title{
UV-induced skin damage improvement effects of solvent fraction from Maekmoondong-tang
}

\author{
Jae-Myo Yu ${ }^{1}$ (D) $\cdot$ Yun-Hwan Kang ${ }^{1} \cdot$ Bo-Mi Kim ${ }^{1} \cdot$ Dong-Hee Kim $^{1} \cdot$ Tae-Soon Park $^{1}$ (]) \\ 맥문동탕 용매 분흭물의 UV에 의한 피부손상 개선 효능평가
}

유재묘 ${ }^{1} \cdot$ 강윤환 $^{1} \cdot$ 김보미 ${ }^{1} \cdot$ 김동희 $^{1} \cdot$ 박태순 $^{1}$

Received: 27 July 2018 / Accepted: 2 September 2018 / Published Online: 30 September 2018

(C) The Korean Society for Applied Biological Chemistry 2018

\begin{abstract}
In this study, we verified the 1-1-diphenyl-2-picrylhydrazyl radical scavenge, 2,2'-azinobis(3-ethylbenzothiazoline-6sulfonic acid) radical scavenge, elastase, tyrosinase inhibitory effect by using the solvent fractions of Maekmoondong-tang hot water extract. As a result, the ethyl acetate fraction (MW-EA) showed the highest inhibitory activity. In cell-based assays, MWEA treatment confirmed a $34 \%(100 \mu \mathrm{g} / \mathrm{mL})$ efficacy in reactive oxygen species inhibitory activity, and at the same concentration, MMPs showed more than 50\% inhibition and tyrosinase inhibited $25 \%(50 \mu \mathrm{g} / \mathrm{mL})$. Therefore Maekmoondong-tang is considered high development potential as a material to improve the skin.
\end{abstract}

Keywords Anti-oxidant - Anti-wrinkle - CCD-986sk - HEM · Maekmoondong-tang $\cdot$ Whitening

\section{서 론}

자외선(UV)은 피부에 많은 영향을 미치는데 염증, 피부암 및 피부 노화(광노화)를 유발할 수 있다[1,2]. 임상에서 노화로 인

Tae-Soon Park $(\bowtie)$

E-mail: taesoon2p@nikom.or.kr

${ }^{1}$ National Development Institute of Korean Medicine, Gyeongsangbuk-do 38540, Republic of Korea

This is an Open Access article distributed under the terms of the Creative Commons Attribution Non-Commercial License (http://creativecommons. org/licenses/by-nc/3.0/) which permits unrestricted non-commercial use, distribution, and reproduction in any medium, provided the original work is properly cited.
한 피부는 미세하고 거친 주름, 색소 침착 및 모세 혈관 확장 등으로 확인할 수 있고, 생물학적으로 봤을 때는 콜라겐 발현 을 억제하는 것을 특징적인 것으로 볼 수 있다[3]. UV에 의한 노화의 경우 프로콜라겐 합성 감소 및 콜라겐의 분해 등으로 인해 노화가 일어난다[4].

UV에 의해 유발되는 피부노화는 활성산소종(reactive oxygen species, ROS)으로 인한 세포막 손상으로 최종적으로는 피부세 포의 기능을 상실하여 주름을 야기시킨다. 그리고 콜라겐과 matrix metalloproteinase (MMP) expression의 기본 메커니즘을 확인하는 것 또한 중요한데, 이에 대한 피부의 초기 반응 중 하 나는 epidermal growth factor receptor와 tumor necrosis factor (TNF)- $\alpha$ receptor와 같은 세포 표면에 발현되는 성장 인자 및 사이토카인 수용체의 활성화를 들 수 있다[5].

또한, UV는 mitogen-activated protein kinases의 활성화를 유도하여 $\mathrm{AP}-1$ 의 발현을 증가시키며 차례로 $\mathrm{MMPs}$ 의 상향 조 절을 유발한다. 증가되는 MMPs로는 MMP-1, MMP-2, MMP9, MMP-13 등이 있으며 이것은 진피의 extracellular matrix (ECM) protein 분해를 야기시킨다[6]. ECM은 피부 탄력성과 수 분 수용력을 유지하는 기능을 하므로 이것의 기능저하는 주름 을 유발한다.

UV는 피부의 melanin 합성과도 관련되어 있는데 melanin은 tyrosinase를 가지고 있는 melanosome 내에서 합성된다. Melanin 합성에 관여하는 특이적 효소로는 tyrosinase, tyrosinase-related protein (TRP)-1 및 TRP-2가 있으며, tyrosinase는 3,4-dihydroxyphenylalanine (DOPA)을 형성하는 tyrosine의 hydroxylation을 촉매하고 $\mathrm{DOPA}$ 를 산화시켜 DOPA quinone을 생성시키는 melanin 생성 속도 제한 효소로 작용한다. TRP-1과 TRP-2는 tyrosinase의 downstream에서 melanin 합성에 관여하며, 이 특이 적 효소는 microphthalmia-associated transcription factor에 의 해서 조절되어 최종적으로 melanin 합성에 관여하는 역할을 한 다[7-9]. Melanin은 피부와 모발의 색을 담당하고 자외선 차단 
에 있어서 중요한 역할을 하기도 하지만, 표피의 melanin 합성 이 증가하게 되면 피부가 어두워지고 미용상 문제가 발생할 수 있다[10-12].

맥문동탕은 맥문동(麥門冬), 진피(陳皮), 반하(牛夏), 백출(白术), 복령(获苓), 소맥(小麥), 인삼(人蓼), 감초(甘草), 오매(鳥梅), 생강 (生薑) 총 10 가지 약재로 구성되어 있으며, 보고된 연구결과로 는 폐활량 개선에 미치는 영향[13], 알레르기 천식[14], 호흡기 점액 생성 및 분비[15], 항암 및 항전이 효능[16] 등이 있는데, 항산화, 주름억제, 미백효과 등에 대한 연구는 진행된 바가 없다. 따라서 본 연구에서는 맥문동탕의 신규 적응증 발굴을 위해 항 산화, 주름억제, 미백효과에 대한 활성을 용매 분획물을 이용하 여 검증하였다.

\section{재료 및 방법}

\section{재료 및 시약}

본 연구에서 사용한 효능 측정 시약은 n-succinyl-(L-Ala) $)_{3}-\mathrm{p}-$ nitroanilide, collagenase from Clostridium histolyticum, potassium persulfate, L-ascorbic acid, L-3,4-dihydroxyphenylalanine (LDOPA), 1-1-diphenyl-2-picryl-hydrazyl (DPPH), 2,2'-azinobis (3-ethylbenzothiazoline-6-sulfonic acid) (ABTS), 3-[4,5-dimethylthiazol-2-yl]-2,5-diphenyl-tetrazolium bromide (MTT)를 Sigma chemical Co. (St. Louis, MO, USA)에서 구입하였고, 맥문동탕 의 구성약재는 2016년 2월 (주)휴먼허브(Gyeongsan-si, Korea) 에서 구입하여 실험에 사용하였다. 지표성분의 경우 hesperidin (Sigma)에서 구입하였으며 narirutin은 한약진흥재단 천연물 물 질은행에서 분양받아서 사용하였다. 세포 배양을 위한 시약으로 는 penicillin/streptomycin, fetal bovine serum (FBS), dulbecco's modified eagle medium (DMEM)을 gibco BRL Co. (Grand Island, New York, USA)에서 구입하였으며, 주름억제 활성 측 정을 위한 시약으로 위한 human tumor necrosis factor- $\alpha$ with carrier, sterile (TNF- $\alpha$ )를 Cell Signaling사(Danvers, MA, USA)에서 구입하였고, 미백활성 검증에는 forskolin (Sigma)을 사용하였다. Primary antibody 및 secondary antibody는 Santa cruz biotechnology Inc. (Santa cruz, CA, USA)에서 구입하여 사용하였다. 주름 개선활성 측정을 위해 procollagen type I Cpeptide kit (Takara Shuzo, Kyoto, Japan), 항산화활성 측정은 ROS-Glo ${ }^{\mathrm{TM}} \mathrm{H}_{2} \mathrm{O}_{2}$ assay kit (Promega, Madison, WI, USA)를 구입하였다.

\section{시료 추출 및 용매 분흭}

맥문동탕 시료 제조는 맥문동(麥門冬) $8 \mathrm{~g}$, 진피(陳皮), 반하(牛 夏), 백출(白术), 복령(获苓), 소맥(小麥)을 각각 $4 \mathrm{~g}$, 인삼(人蔘), 감초(甘草), 생강(生薑)을 각각 $2 \mathrm{~g}$, 오매(鳥梅) 1 개 준비하는 것 을 1 회 분량으로 하였다. 여기에 10 배의 물을 넣고 3 시간씩 추 출하는 방법으로 3 회 반복하였다. 이 방법으로 3회 추출하고 $(111 \mathrm{~g})$ 시료 $37.28 \mathrm{~g}$ 을 얻었으며 수율은 $33.6 \%$ 로 확인되었다. 확보된 추출물 중 $10 \mathrm{~g}$ 으로 용매분획법을 통해 $\mathrm{n}$-hexane $(0.35$ $\mathrm{g})$, ethyl acetate $(0.29 \mathrm{~g})$, butanol $(1.42 \mathrm{~g})$ water $(7.74 \mathrm{~g})$ 분 획물을 확보하였다.
Table 1 Analytical conditions of HPLC

\begin{tabular}{|c|c|c|c|}
\hline Instrument & Agilent $1260 \mathrm{In}$ & nity & \\
\hline Column & YMC Triart $\mathrm{C}_{18}$ & $250 \times 4.6 \mathrm{~mm} \mathrm{I.}$ & um) \\
\hline Injection volume & $20 \mu \mathrm{L}$ & $\begin{array}{l}\text { Autosampler } \\
\text { temperature }\end{array}$ & $4{ }^{\circ} \mathrm{C}$ \\
\hline Flow rate & $1.0 \mathrm{~mL} / \mathrm{min}$ & $\begin{array}{l}\text { Column } \\
\text { temperature }\end{array}$ & $25^{\circ} \mathrm{C}$ \\
\hline Mobile phase & $\begin{array}{l}\text { A: water } \\
\text { B: Acetonitrile }\end{array}$ & Scan range & $284 \mathrm{~nm}$ \\
\hline \multirow{8}{*}{ Gradient } & Time (min) & $\mathrm{A}(\%)$ & B (\%) \\
\hline & 0 & 90 & 10 \\
\hline & 10 & 85 & 15 \\
\hline & 25 & 70 & 30 \\
\hline & 40 & 50 & 50 \\
\hline & 55 & 20 & 80 \\
\hline & 60 & 90 & 10 \\
\hline & 65 & 90 & 10 \\
\hline
\end{tabular}

\section{HPLC 분석}

맥문동탕 열수추출물의 에틸아세테이트 분획물(MW-EA)이 포 함하고 있는 hesperidin과 narirutin의 함량을 확인하기 위해 Table 1의 조건에서 분석을 수행하였다. HPLC 분석에 사용된 칼럼 및 장비는 $\mathrm{YMC}$ Triart $\mathrm{C} 18(4.6 \times 250 \mathrm{~mm}$, I.D. $5 \mu \mathrm{m}$, YMC Co., Ltd., Kyoto, Japan)과 Agilent 1260 Infinity (Agilent, Folsom, CA, USA)를 사용하였다.

시료의 standard 물질 함량에 대한 분석은 '의약품 등 분석법 의 벨리데이션 가이드라인(식품의약품안전처)'을 참고하여 수행 하였다.

\section{세포 배양}

세포 배양은 DMEM/high glucose (10\% FBS, $1 \%$ penicillin/ streptomycin 첨가) 배지와 HEM glowth medium $(0.68 \%$ Freezing medium, $1 \%$ penicillin/streptomycin 첨가) 배지를 사 용하여 CCD-986sk cell과 $\mathrm{HEM}$ cell을 $37^{\circ} \mathrm{C}, \quad 5 \% \quad \mathrm{CO}_{2}$ incubator에서 배양하였다.

\section{MTT assay에 의한 세포 독성 측정}

시료의 세포 독성을 확인하기 위해 96 well plate에 CCD$986 \mathrm{sk}$ 와 HEM 세포를 $1 \times 10^{4}, 3 \times 10^{4}$ cells/well로 분주하고 24 시 간동안 안정화시켰다. 그 후 시료를 농도별로 처리하고 $37^{\circ} \mathrm{C}$, $5 \% \mathrm{CO}_{2}$ 의 조건으로 incubator에서 48시간 동안 배양하였다. $5 \mathrm{mg} / \mathrm{mL}$ 의 MTT 시약을 반응시킨 후 microplate reader를 이용 하여 $540 \mathrm{~nm}$ 에서 흡광도를 측정하였다[17].

\section{항산화 활성 측정}

항산화 활성 검증은 $\mathrm{DPPH}$ radical scavenging[18]과 $\mathrm{ABTS}$ radical scavenging[19] 그리고 ROS-Glo ${ }^{\mathrm{TM}} \mathrm{H}_{2} \mathrm{O}_{2}$ assay kit를 사용하여 측정하였다. $\mathrm{ROS}$ 생성량 측정의 경우 96 well plate 에 CCD-986sk cell을 $1 \times 10^{4}$ cells/well의 양으로 분주하여 시료 를 처리하고 ROS 발생양을 microplate reader로 측정하였다. 
Table 2 Intra-day accuracy of Hesperidin

\begin{tabular}{|c|c|c|c|c|c|c|}
\hline \multirow{2}{*}{ conc. of sample $(\mu \mathrm{g} / \mathrm{mL})$} & \multicolumn{3}{|c|}{ measured conc. $(\mu \mathrm{g} / \mathrm{mg})$} & \multirow{2}{*}{ Mean } & \multirow{2}{*}{$\mathrm{SD}$} & \multirow{2}{*}{$\%$ RSD } \\
\hline & run1 & run2 & run3 & & & \\
\hline 1000 & 17.0692 & 15.8055 & 16.5641 & 16.4796 & 0.6361 & $2.73 \%$ \\
\hline
\end{tabular}

Table 3 Intra-day accuracy of Narirutin

\begin{tabular}{|c|c|c|c|c|c|c|}
\hline \multirow{2}{*}{ conc. of sample $(\mu \mathrm{g} / \mathrm{mL})$} & \multicolumn{3}{|c|}{ measured conc. $(\mu \mathrm{g} / \mathrm{mg})$} & \multirow{2}{*}{ Mean } & \multirow{2}{*}{$\mathrm{SD}$} & \multirow{2}{*}{$\%$ RSD } \\
\hline & run1 & run2 & run3 & & & \\
\hline 1000 & 12.1877 & 12.7189 & 12.6987 & 12.5351 & 0.3011 & $1.70 \%$ \\
\hline
\end{tabular}

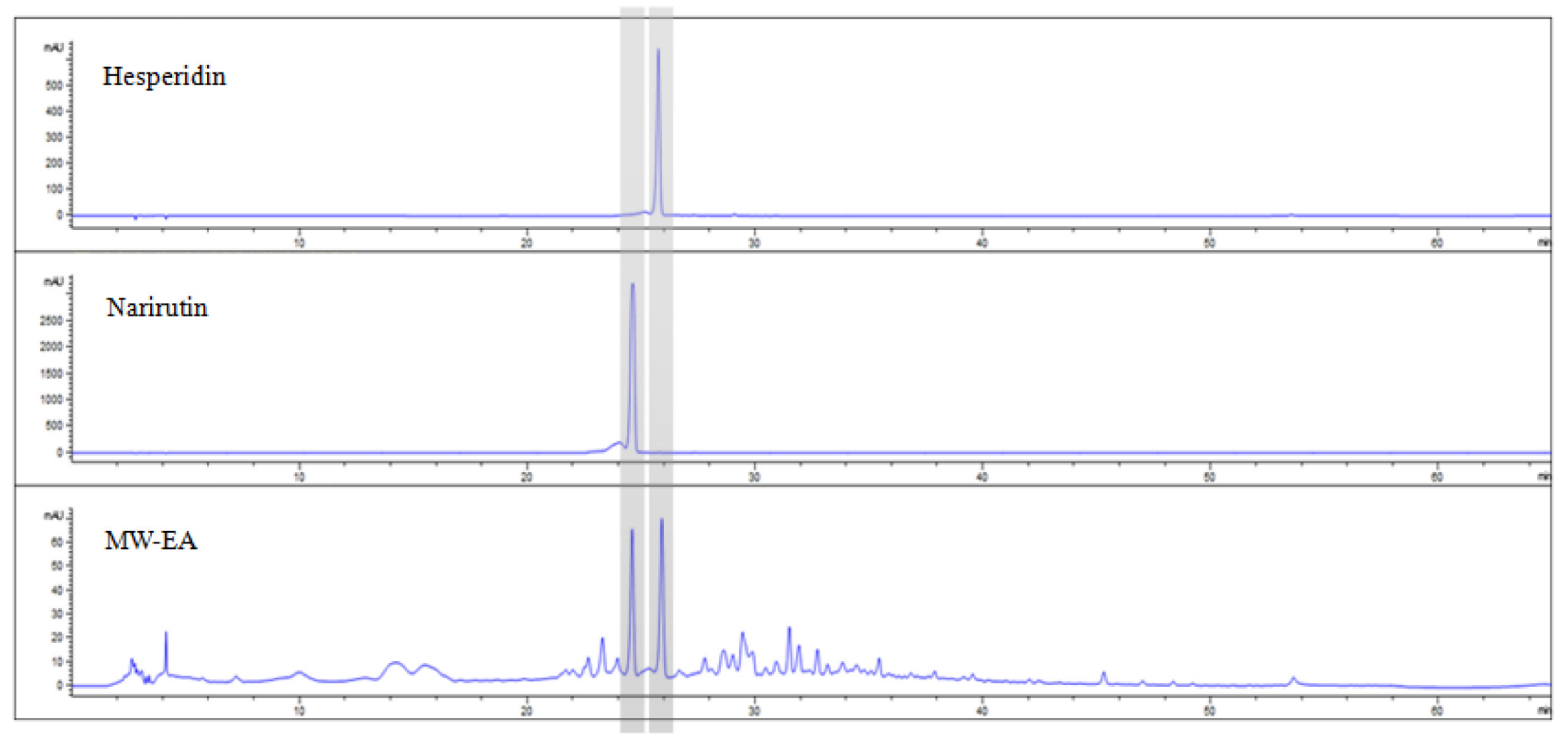

Fig. 1 Chromatogram of hesperidin, narirutin and MW-EA fraction

\section{주름 억제 활성 측정}

Elastase 저해활성은 다음과 같이 진행하였다. $40 \mu \mathrm{L}$ 의 시료를 96 well plate에 넣고 $50 \mathrm{mM}$ tris- $\mathrm{HCl}$ buffer $(\mathrm{pH}$ 8.6)로 기질 과 효소를 녹인후 처리한다. 30 분간 반응시킨 후 $445 \mathrm{~nm}$ 에서 측정하였다[20]. Procollagen type-I 생합성 측정은 96 well plate에 CCD-986sk cell을 $1 \times 10^{4}$ cells/well로 분주하여 UV-B $\left(20 \mathrm{~mJ} / \mathrm{cm}^{2}\right)$ 와 $\mathrm{TNF}-\alpha(10 \mathrm{ng} / \mathrm{mL})$ 를 처리한 후 48 시간 배양하 였다. 이것의 상등액을 취하여 propeptide의 양을 측정하였다.

\section{미백 활성 측정}

미백 활성은 mushroom tyrosinase $(110 \mathrm{U} / \mathrm{mL})$ 를 사용하여 측정 하였다. $0.175 \mathrm{M}$ sodium phosphate buffer (pH 6.8)로 10 $\mathrm{mM} \mathrm{L}-\mathrm{DOPA}$ 와 효소를 녹인후 각 반응구에 넣고 $37^{\circ} \mathrm{C}$ 에서 2 $\min$ 간 반응시켜 $492 \mathrm{~nm}$ 에서 측정하였다[21].

\section{Western blot을 통한 주름 및 미백 관련 단백질의 발현 측정} CCD-986sk, HEM cell을 6 well plate에 각각 $1 \times 10^{5}$ cells/ well, $3 \times 10^{5}$ cells/well로 분주하고 24 시간 동안 안정화시켰다. 그 후 UV-B $\left(20 \mathrm{~mJ} / \mathrm{cm}^{2}\right)$, TNF- $\alpha(10 \mathrm{ng} / \mathrm{mL})$ 또는 forskolin $(1 \mathrm{nM})$ 을 시료와 함께 48시간 동안 배양하였다. 처리된 세포를 lysis buffer로 모은후 bradford assay를 통해 정량하였으며 $10 \%$
SDS-PAGE로 전기영동 하였다. PVDF membrane에 transfer하 는 과정과 primary\&secondary antibody를 반응시키는 것을 통 해 결과를 측정하였다. 결과는 ImageQuant LAS-4000 (GE life sciences, Taipei, Taiwan)를 사용하여 수치화 하였다.

\section{통계처리}

SPSS 10.0으로 통계처리 하였으며, $t$-test를 통해 유의수준 $p<$ 0.05 에서 분산분석(ANOVA: analysis of variance)으로 검증하였다.

\section{결과 및 고찰}

\section{HPLC 분석}

MW-EA에 포함되어 있는 지표성분 hesperidin과 narirutin의 함 량을 분석한 결과 Table 2, 3과 같다. Standard 물질을 이용한 calibration curve를 통해 hesperidin은 MW-EA $1,000 \mu \mathrm{g}$ 당 $16.480 \pm 0.636 \mu \mathrm{g}$ 을 포함하고 있고, narirutin의 경우 $12.535 \pm$ $0.301 \mu \mathrm{g}$ 을 포함하는 것을 알 수 있었다. 또한 standard 물질과 시료의 chromatogram을 확인한 결과 Fig. 1과 같았다. 본 연구 에서는 지표성분(hesperidin, narirutin)의 함량과 성분 profile pathern이 확인된 MW-EA를 주요 시험 시료로 이용하였다. 

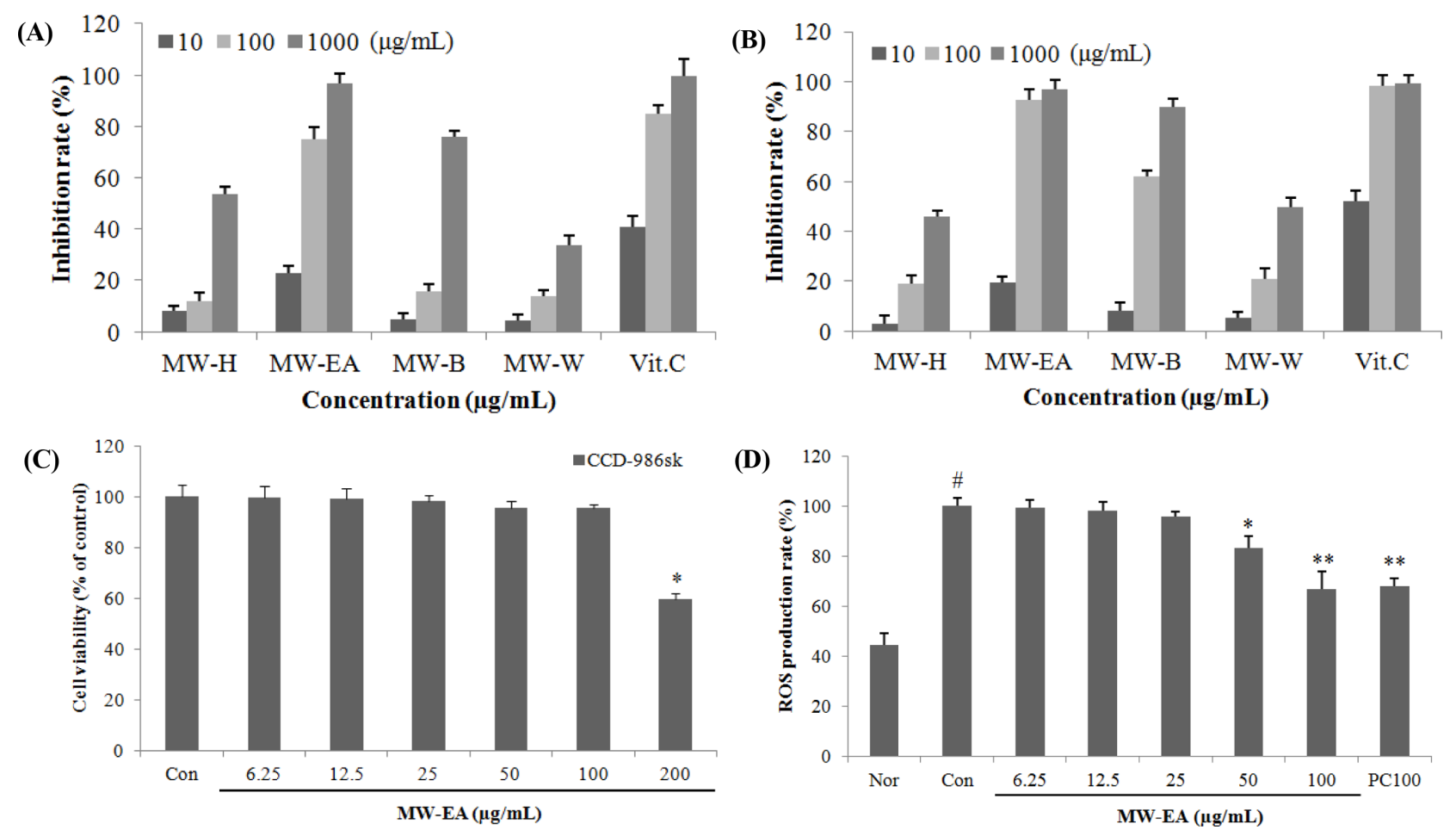

Fig. 2 Anti-oxidant activity of solvent fractions isolated from Maekmoondong-tang. (A), DPPH radical activity; (B), ABTS cation radical activity; (C), cytotoxicity on CCD-986sk cell; (D), ROS production rate. MW-H, hexane fraction of water extract from Maekmoondong-tang; MW-EA, ethyl acetate fraction of water extract from Maekmoondong-tang; MW-B, butanol fraction of water extract from Maekmoondong-tang; MW-W, water fraction of water extract from Maekmoondong-tang; Vit. C, L-ascorbic acid; Nor, non-treated; Con, treated with UV-B+TNF- $\alpha$; PC100, treatment of adenosine by $100 \mu \mathrm{g} / \mathrm{mL}$. Result are means $\pm \mathrm{SD}$ of triplicate data. ${ }^{*} p<0.05$ vs. Nor. ${ }^{*} p<0.05,{ }^{*} p<0.01$ vs. Con

\section{항산화 활성}

$\mathrm{DPPH}, \mathrm{ABTS}$ radical 소거능 측정과 $\mathrm{ROS}-\mathrm{Glo}^{\mathrm{TM}} \mathrm{H}_{2} \mathrm{O}_{2}$ assay $\mathrm{kit}$ 를 이용한 ROS 생성량 측정을 통해서 맥문동탕 열수추출물 의 헥산(MW-H), 에틸아세테이트(MW-EA), 부탄올(MW-B), 물 (MW-W) 분획물의 항산화 효과를 확인하였다. DPPH radical 소거능 측정에서 MW-EA가 가장 우수한 효과를 나타냈는데 $100,1,000 \mu \mathrm{g} / \mathrm{mL}$ 의 농도에서 각각 $76,96 \%$ 로 확인되었다(Fig. 2A). 기존연구에서는 잘피 물추출물이 $1,000 \mu \mathrm{g} / \mathrm{mL}$ 에서 $87.64 \%$ [22], 겉보리에서 배양한 영지버섯 추출물은 동일 농도에서 약 $10 \%[23]$ 의 저해율을 보여주었다.

ABTS radical 소거능에서는 MW-EA, MW-B, MW-W, MW$\mathrm{H}$ 의 순서로 저해활성이 높았으며 $\mathrm{MW}-\mathrm{EA}$ 의 경우 $100,1,000$ $\mu \mathrm{g} / \mathrm{mL}$ 에서 각각 $92,96 \%$ 의 억제효과를 보여주었다(Fig. 2B). 반면에 이슬송이버섯의 물추출물은 $1,250 \mu \mathrm{g} / \mathrm{mL}$ 에서 약 $20 \%$ [24], 유자과즙 물추출물의 경우 $1,000 \mu \mathrm{g} / \mathrm{mL}$ 에서 약 $10 \%[25]$ 의 저해효과가 보고되었다.

세포를 이용한 항산화 활성 검증은 ROS- $\mathrm{Glo}^{\mathrm{TM}} \mathrm{H}_{2} \mathrm{O}_{2}$ assay kit로 측정하였으며 앞서 $\mathrm{DPPH}, \mathrm{ABTS}$ radical 소거능에서 가 장 저해효과가 우수한 $\mathrm{MW}-\mathrm{EA}$ 를 처리하여 확인하였다. 또한 세포 실험을 위해 CCD-986sk cell에서 시료의 세포 독성을 검 증하였고, 그 결과 $6.25,12.5,25,50,100 \mu \mathrm{g} / \mathrm{mL}$ 의 농도에서 세포독성이 나타나지 않았다(Fig. 2C). 따라서 $6.25-100 \mu \mathrm{g} / \mathrm{mL}$ 의 농도에서 $\mathrm{ROS}$ 저해활성을 검증하였으며 그 결과 50,100 $\mu \mathrm{g} / \mathrm{mL}$ 의 농도에서 약 $17,34 \%$ 의 억제활성을 확인하였다(Fig.
2D). 이는 $\mathrm{MW}-\mathrm{EA}$ 가 $\mathrm{UV}$ 에 의해 증가된 $\mathrm{ROS}$ 를 잠재적으로 억제 할 수 있음을 나타낸다.

\section{주름 억제}

맥문동탕의 주름억제 효능을 검증하기 위해 elastase 억제활성 을 측정하였다. 시료는 $\mathrm{MW}-\mathrm{H}, \mathrm{MW}-\mathrm{EA}, \mathrm{MW}-\mathrm{B}, \mathrm{MW}-\mathrm{W}$ 로 측 정하였으며 $\mathrm{MW}-\mathrm{EA}$ 가 $10,100,1,000 \mu \mathrm{g} / \mathrm{mL}$ 의 농도에서 10 , $21,43 \%$ 의 효과로 가장 우수한 저해효과를 나타내었다(Fig. $3 \mathrm{~A})$. 기존 연구에서는 운지버섯 자실체 열수추출물이 $100 \mu \mathrm{g} /$ $\mathrm{mL}$ 에서 $18.6 \%$ 의 저해활성을 보여주었다[26].

Elastase 억제활성 측정에서 가장 우수한 $\mathrm{MW}-\mathrm{EA}$ 를 이용해서 procollagen type-I C peptide 생성량 확인 및 광노화 유도 인 자인 MMPs에 대해서 western blot을 실시하였다. Procollagen 은 collagen의 전구체이고 이것을 측정하기 위해 $\mathrm{c}$-말단을 인지 하는 항체를 이용하여 생성량을 측정하는 방법으로 확인하였다. CCD-986sk cell을 이용하여 MW-EA를 $6.25,12.5,25,50$, $100 \mu \mathrm{g} / \mathrm{mL}$ 의 농도로 처리하였고 아무처리도 하지 않은 대조군 과 비교하였을 때 $100 \mu \mathrm{g} / \mathrm{mL}$ 에서 $87.8 \%$ 의 합성율을 보여주었 다(Fig. 3B).

$\mathrm{CCD}-986 \mathrm{sk}$ cell에 $\mathrm{MW}-\mathrm{EA}$ 를 처리하여 주름 형성에 작용하 는 것으로 알려진 MMP-1, -2, -9, -13에 대한 단백질의 발현을 확인하였다. MW-EA는 $6.25,12.5,25,50,100 \mu \mathrm{g} / \mathrm{mL}$ 의 농도 로 처리하였고 최고 농도인 $100 \mu \mathrm{g} / \mathrm{mL}$ 에서 $\mathrm{MMP}-1,-2,-9$, 13 의 순서로 $88,49,56,66 \%$ 의 억제효과를 보여주었다(Fig. 

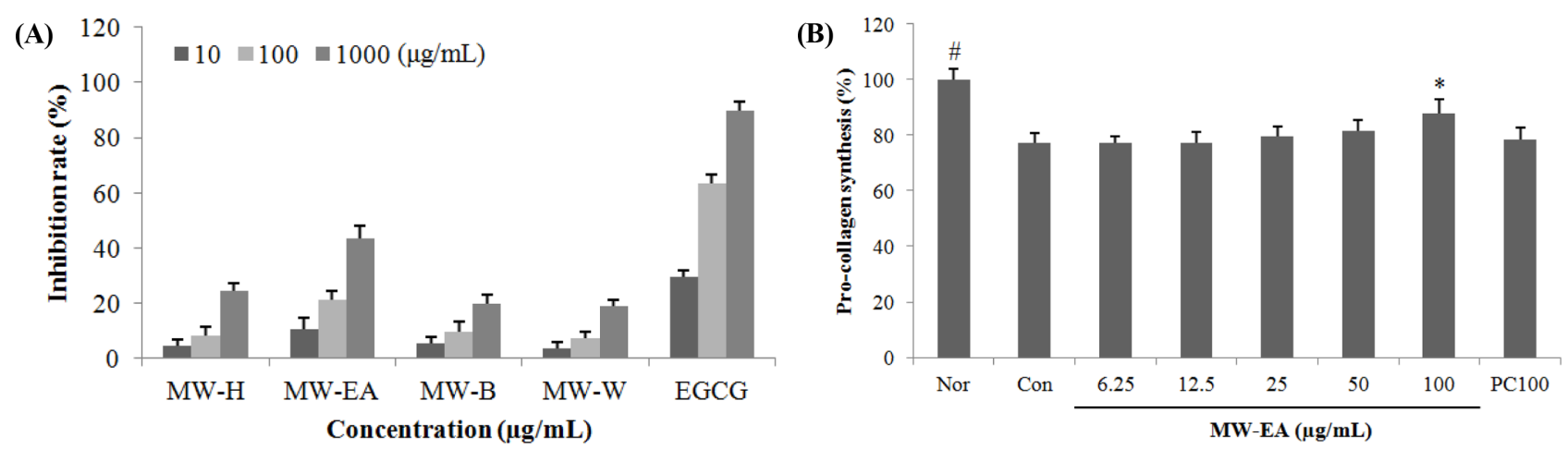

Fig. 3 Anti-wrinkle activity of solvent fractions isolated from Maekmoondong-tang. (A), Elastase inhibition rate; (B), procollagen synthesis rate. MW$\mathrm{H}$, hexane fraction of water extract from Maekmoondong-tang; MW-EA, ethyl acetate fraction of water extract from Maekmoondong-tang; MW-B, butanol fraction of water extract from Maekmoondong-tang; MW-W, water fraction of water extract from Maekmoondong-tang; EGCG, epigallocate chin-3-gallate; Nor, non-treated; Con, treated with UV-B+TNF- $\alpha$; PC100, treatment of adenosine by $100 \mu \mathrm{g} / \mathrm{mL}$. Result are means \pm SD of triplicate data. ${ }^{\#} p<0.05$ vs. Con. ${ }^{*} p<0.05$ vs. Nor
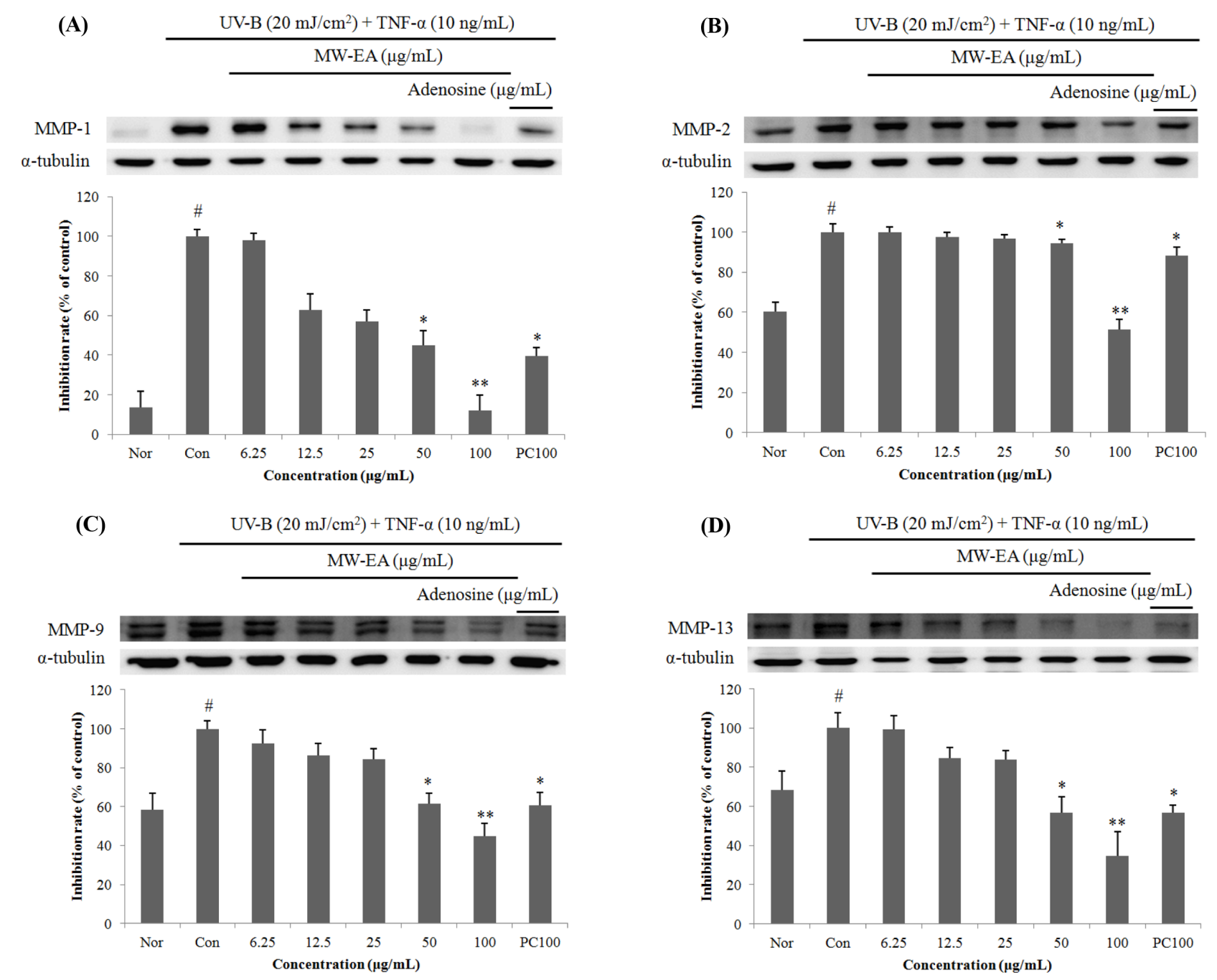

Fig. 4 Wrinkle-related protein expression rate of Maekmoondong-tang on fibroblast cell (CCD-986sk). Histogram show the densitometry of protein normalized to $\alpha$-tubulin. (A), MMP-1 protein expression rate; (B), MMP-2 protein expression rate; (C), MMP-9 protein expression rate; (D), MMP-13 protein expression rate. Nor, non-treated; Con, treated with UV-B+TNF- $\alpha$; PC100, treatment of adenosine by $100 \mu \mathrm{g} / \mathrm{mL}$. The data represent the mean \pm SD of three separate experiments. ${ }^{*} p<0.05$ vs. Nor. ${ }^{*} p<0.05$ and ${ }^{* *} p<0.01$ vs. Con 


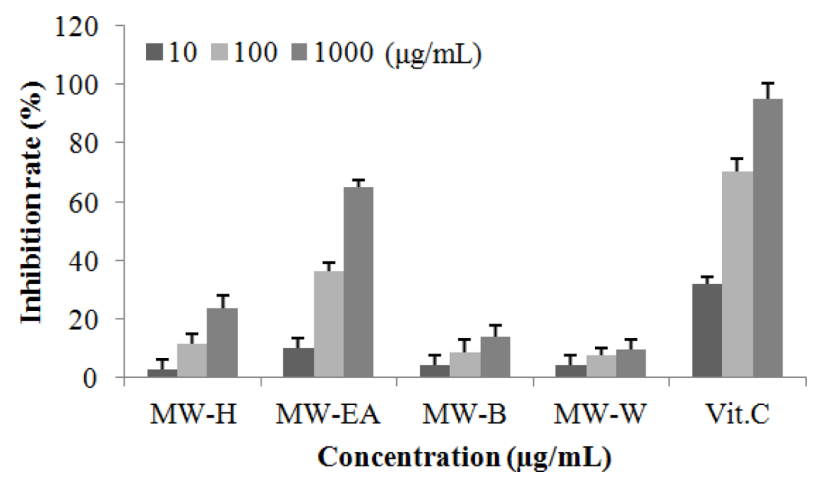

Fig. 5 Tyrosinase inhibition rate of solvent fractions isolated from Maekmoondong-tang. MW-H, hexane fraction of water extract from Maekmoondong-tang; MW-EA, ethyl acetate fraction of water extract from Maekmoondong-tang; MW-B, butanol fraction of water extract from Maekmoondong-tang; MW-W, water fraction of water extract from Maekmoondong-tang; Vit. C, L-ascorbic acid. Result are means \pm SD of triplicate data

4A-D). 기존 연구에서는 참깨 에탄올 추출물이 동일한 농도에 서 MMP-1 protein의 발현을 약 $40 \%$ 억제하였다는 보고가 있 다[27]. 이 결과들을 통해 $\mathrm{MW}-\mathrm{EA}$ 의 주름 억제 효능을 예측할 수 있었다.

\section{미백 활성}

맥문동탕의 미백 효과는 tyrosinase 억제활성과 western blot을 통해 미백관련 인자의 발현 확인으로 검증하였다. 맥문동탕 분 획물의 tyrosinase 저해효과는 MW-EA, MW-H, MW-B, MW$\mathrm{W}$ 의 순서로 우수하였으며 $1,000 \mu \mathrm{g} / \mathrm{mL}$ 의 농도에서 각 각 65 , $23,13,9 \%$ 로 나타났다(Fig. 5). 기존 보고된 연구에서는 양제 근 에탄올 추출물이 동일한 농도에서 $78 \%$ [28], 육종용 추출물 은 $2,000 \mu \mathrm{g} / \mathrm{mL}$ 에서 $68 \%$ 의 저해 활성을 보여주었다[29].

Western blot을 통해 미백 인자인 MITF, tyrosinase, TRP-1, TRP-2를 확인하였다. 미백관련 인자의 발현을 확인하기에 앞서 $\mathrm{HEM}$ cell에서 MW-EA의 세포독성을 검증하였고 $6.25,12.5$, $25,50 \mu \mathrm{g} / \mathrm{mL}$ 농도에서 세포독성이 관찰되지 않았다(Fig. 6A). MITF, tyrosinase, TRP-1, TRP-2에 대한 저해 효과는 $50 \mu \mathrm{g}$ $\mathrm{mL}$ 의 농도에서 각 각 $10,25,6,12 \%$ 로 나타났다(Fig. 6B-E). 반면에 도인승기탕은 동일한 농도에서 MITF는 $20 \%$, tyrosinase 는 $13 \%, \mathrm{TRP}-1$ 은 $12 \%, \mathrm{TRP}-2$ 는 $15 \%$ 의 억제효과를 보여주었 다[30]. 이 결과들을 통해 MW-EA의 미백 활성을 확인하였다.

본 연구를 통해 맥문동탕의 피부개선효과를 검증함으로써 한 방 처방을 이용한 피부개선 천연 소재의 개발 가능성을 확인하 였다.

\section{초 록}

맥문동탕 열수추출물의 용매분획물을 이용하여 1-1-diphenyl-2-picrylhydrazyl radical scavenge, 2,2'-azinobis(3-ethylbenzothiazoline-6sulfonic acid) radical scavenge, elastase, tyrosinase 억제 효과 를 검증하였고 그 결과 에틸아세테이트 분획물(MW-EA)에서 가
장 우수한 저해활성을 보여주었다. 세포를 이용한 활성 검증에 서는 MW-EA를 처리하였을 때 ROS 저해활성에서 34\% (100 $\mu \mathrm{g} / \mathrm{mL}), \mathrm{MMPs}$ 저해 $50 \%(100 \mu \mathrm{g} / \mathrm{mL})$ 이상, 미백 활성에서는 tyrosinase를 $25 \%(50 \mu \mathrm{g} / \mathrm{mL})$ 억제하는 것을 확인 하였다. 따라 서 맥문동탕은 피부개선 소재로서 개발 가능성이 높다고 사료 된다.

Keywords 맥문동탕 - 멜라닌세포 - 미백 · 섬유아세포 - 주름 억제 · 항산화

감사의 글 이 연구는 중소벤처기업부 지역특화(주력)산업육성사업(R0005615) 의 일환으로 수행하였음.

\section{References}

1. Armstrong BK, Kricker A (2001) The epidemiology of UV induced skin cancer. J Photochem Photobiol B 63(1): 8-18

2. Kligman LH (1989) The ultraviolet-irradiated hairless mouse: a model for photoaging, J Am Acad Dermatol 21: 623-631

3. Chung JH (2003) Photoaging in Asians, Photodermatol. Photoimmunol. Photomed 19: 109-121

4. Busca R, Ballotti R (2000) Cyclic AMP a key messenger in the regulation of skin pigmentation. Pigment Cell Res 13; 60-69

5. Rittie L, Fisher GJ (2002) UV-light-induced signal cascades and skin aging. Ageing Res Rev 1: 705-720

6. Quan T, Qin Z, Xia W, Shao Y, Voorhees JJ, Fisher GJ (2009) Matrixdegrading metalloproteinases in photoaging. J Investig Dermatol Symp Proc 1: 20-24

7. Bentley NJ, Eisen T, Goding CR (1994) Melanocyte-specific expression of the human tyrosinase promoter: activation by the microphthalmia gene product and role of the initiator. Mol Cell Biol 14: 7996-8006

8. Hodgkinson CA, Moore KJ, Nakayama A, Steingrimsson E, Copeland NG, Jenkins NA, Amheiter H (1993) Mutations at the mouse microphthalmia locus are associated with defects in a gene encoding a novel basic-helix-loophelix-zipper protein. Cell 74: 395-404

9. Steingrimsson E, Moore KJ, Lamoreux ML, Ferre-D'Amare AR, Burley SK, Zimring DC, Skow LC, Hodgkinson CA, Arnheiter H, Copeland NG (1994) Molecular basis of mouse microphthalmia (mi) mutations helps explain their developmental and phenotypic consequences. Nat Genet 8: 256-263

10. Hearing VJ, Jimenez M (1989) Analysis of mammalian pigmenta-tion at the molecular level. Pigment Cell Res 2: 75-85

11. Kobayashi $T$, Urabe $K$, Winder A, Jimenez-Cervantes C, Imokawa G, Brewington T, Solano E, Garcia-Borron JC, Hearing VJ (1994) Tyrosinase related protein 1 (TRP1) functions as a DHICA oxidase in melanin biosynthesis. EMBOJ 13: 5818-5825

12. Yokoyama K, Suzuki H, Yasumoto K, Tomita Y, Shibahara S (1994) Molecular cloning and functional analysis of a cDNA coding for human DOPAchrome tautomerase/tyrosinase-related protein-2. Biochim Biophys Acta 1217: 317-321

13. Park DI (2013) Effects of maekmundong-tang on the improvement of lung capacity. Herbal formula science 21(2): 165-172

14. Park S, Sohn SH, Jung KH, Lee KY, Yeom YR, Kim GE, Bae H (2014) The effects of Maekmoondong-tang on cockroach extract-induced allergic asthma. Evidence-Based Complementary and Alternative Medicine 2014: 12

15. Sung HK, Min SY, Kim JH (2013) Effect of macmundongtang on production and secretion of respiratory mucus. J Pediatrics Kor Med 27(1): 69-81

16. Cheon MS, Chun JM, Yoon TS, Lee A, Moon BC, Choo BK, Kim HK (2009) Anti-carcinogenetic and Anti-metastatic Effects of Extract from 


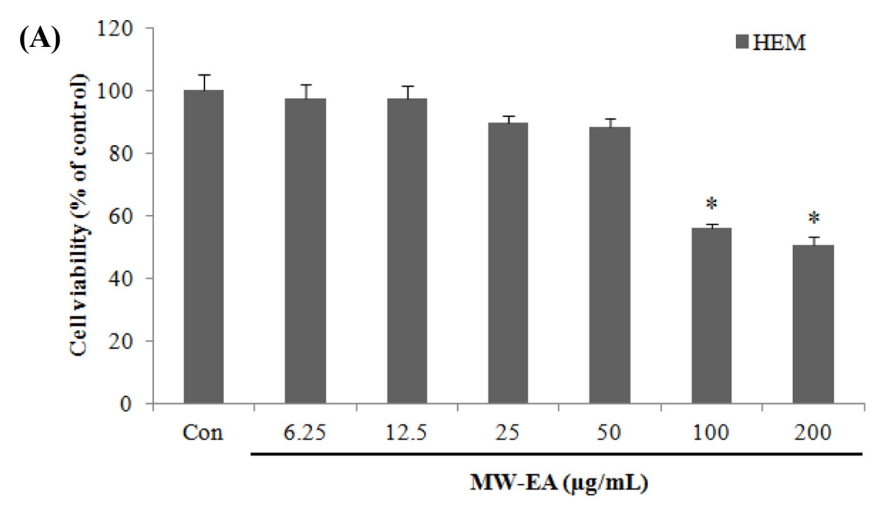

(B)
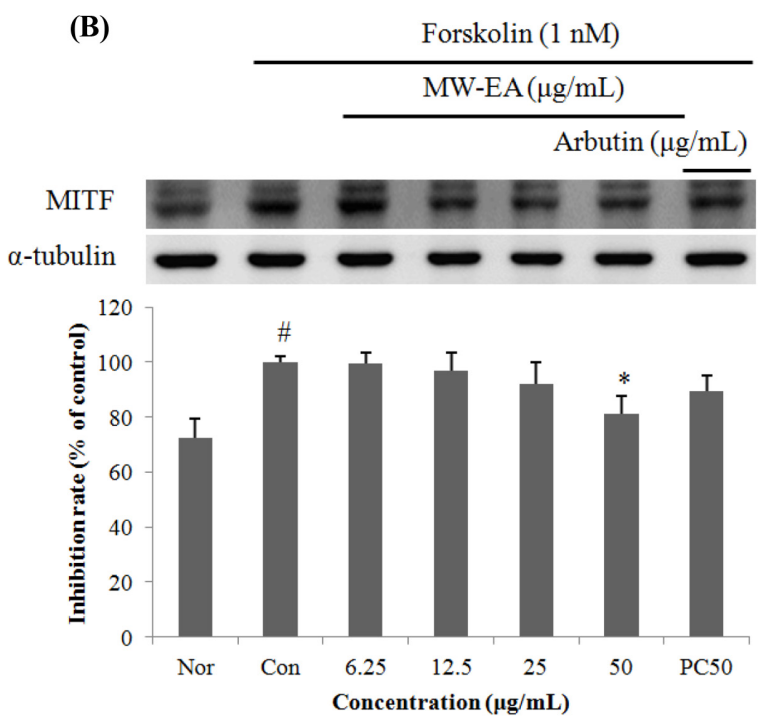

(D)

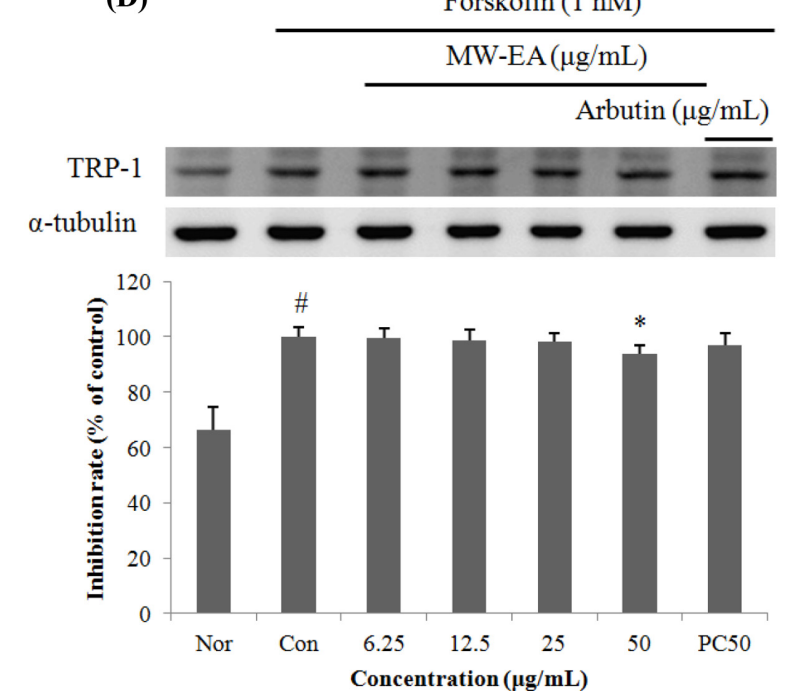

(C)
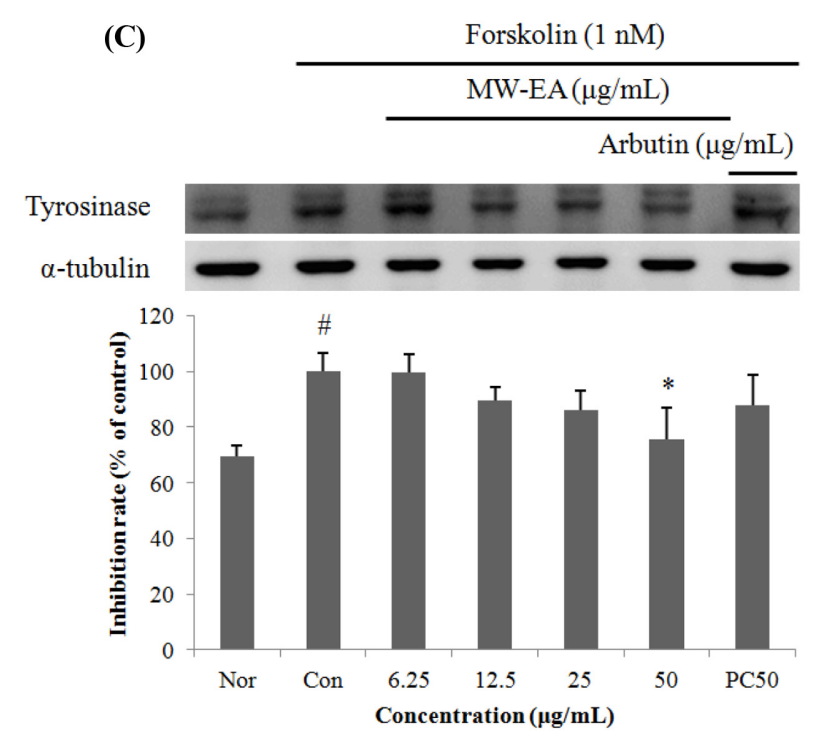

(E)
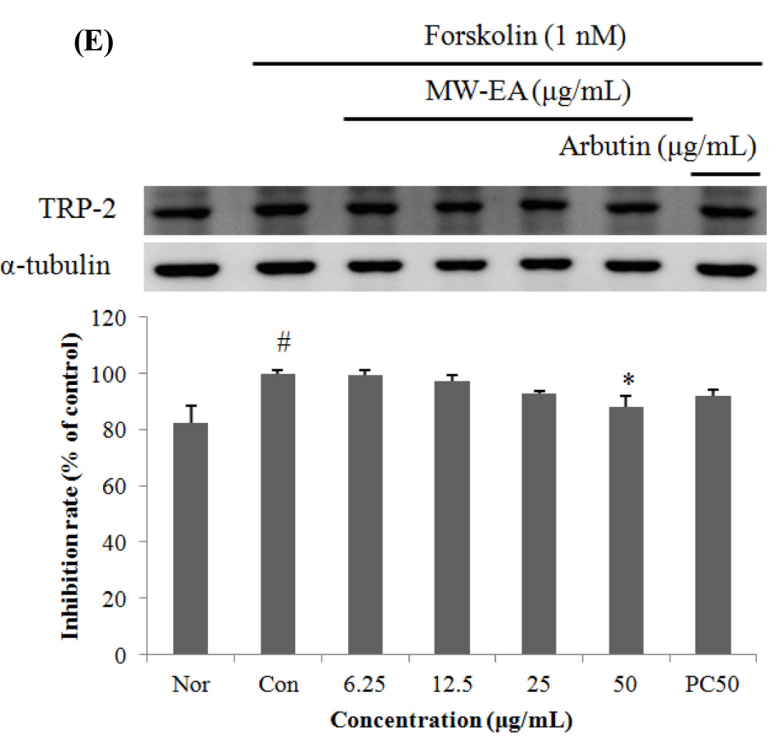

Fig. 6 Whitening-related protein expression rate of Maekmoondong-tang on melanocyte cell (HEM). Histogram show the densitometry of protein normalized to $\alpha$-tubulin. (A), cytotoxicity on HEM cell; (B), MITF protein expression rate; (C), Tyrosinase protein expression rate; (D), TRP-1 protein expression rate; (E), TRP-2 protein expression rate. Nor, non-treated; Con, treated with Forskolin; PC50, treatment of arbutin by $50 \mu \mathrm{g} / \mathrm{mL}$. The data represent the mean \pm SD of three separate experiments. ${ }^{\sharp} p<0.05$ vs. Nor. ${ }^{*} p<0.05$ vs. Con 
Maekmoondong-tang in HepG2 Cells. Kor J Herbology 24(3): 161-167

17. Carmichael J, DeGraff WG, Gazdar AF, Minna JD, Mitchell JB (1987) Evaluation of a tetrazolium based semiautomated colorimetric assay: assessment of chemosen- sitivity

18. Blois MS (1958) Antioxidant determinations by the use of a stable free radical. Nature 181: 1199-1200

19. Re R, Pellegrini N, Proteggente A, Yang M, Rice-Evans C (1999) Antioxidant activity applying an improved ABTS radical cation decolorization assay. Free Radical Biol Med 26: 1231-1237

20. Cannell RJ, Kellam SJ, Owsianka AM, Walker JM (1998) Results of a large scale screen of microalgae for the production of protease inhibitors. Planta Med 54: 10-14

21. Yagi A, Kanbara T, Morinobu N (1986) The effect of tyrosinase inhibition for aloe. Planta medica 3981: 517-519

22. Park SH, Kim KBWR, Kim MJ, Im MH, Ahn DH (2017) Antioxidant Effect of Zostera marina Ethanol and Water Extracts. J Life Sci 27(3): 346-350

23. Seo KH, Kim YH, Lee YM, Ghosh M, Park KM, Park DH, Kim JS Lim BO (2017) Evaluation of Anti-Oxidant and Anti-Inflammatory Activities of Ganoderma lucidum Cultured on Hulled Barley. Kor J Med Crop Sci 25(1): 29-36

24. Jang HL, Park SY, Nam JS (2017) Effect of Extraction Solvent on the
Antioxidant Activity of Lentinula edodes GNA01 Extract. Kor J Food Nutr 30(1): 51-58

25. Lee SH, Lee MS (2017) The Study of Physiological and Antimicrobial Activities on the Citrus Junos Extracts with its Textures and Skin. J Kor Acad-Ind 18(4): 67-74

26. Choi BY, Lee HH (2017) Antioxidant and Physiological Activities of Coriolus versicolor Fruit Body Crude Extracts. J Kor Acad-Ind 17(8): 415-422

27. Joo DH, Yoo DH, Lee JY (2016) A Study on the Anti-wrinkle Activities of Sesamum indicum L. Ethanol Extracts on CCD-986sk. J Soc Cosmet Sci Kor 42(4): 377-385

28. Yang SA, Seo GE, Pyo BS, Kim SM, Choi CH (2017) Antioxidant and Tyrosinase Inhibitory Activity of Extract Rumex japonicus HOUTT Root and Its Fractions. Kor J Med Crop Sci 25(1): 10-15

29. Yang WT, Kim KS, Kwon YS, Kim DH, Kim DH (2016) Whitening and anti-aging effects of Cistanche deserticola extract. J Plant Biotechnol 43: 492-499

30. Hwang JY, Kim DH, Kim HJ, Hwang EY, Park TS, Lee JY, Son JH (2012) Effects of Doinsenggitang on Melanin Synthesis and Gene Expression Inhibition in B16F10 Melanoma Cells. J Life Sci 22(3): 318323 